\title{
How the Civil Rights Movement Defined and Defied the 1960s
}

\author{
By David Goldfield, Fulbright Chair in American Studies, Uppsala \\ University
}

Although historians initially viewed the 1960s as a discrete decade of major change in American society and culture most of us today look upon those years as parts of two distinct eras. In my book, The American Journey (Prentice Hall, 2001, second edition), I call the years from 1953 to 1964, the Confident Years and the period from 1965 to 1980, an era when the US was "Shaken to the Roots."

In the first period, the US was emerging from the uncertain postwar years to unprecedented economic prosperity, political stability, and a culture built around families and children. Federal policies enabled millions of Americans to fulfill the dream of owning a home, typically in the suburbs, and legislation facilitated large numbers of returning servicemen to obtain a college education for free, quickening their move up the socioeconomic ladder. In 1954, the U.S. Supreme Court decision in Brown v. Board of Education of Topeka, Kansas which struck down school desegregation, offered the promise of a better society built on racial equality. In 1955, Dr. Jonas Salk invented the polio vaccine conquering a killer and crippler of children through the ages. And, by 1956, millions of teens were bopping to a new musical phenomenon called rock 'n' roll.

The civil rights movement defined and epitomized these confident years in four ways. First, the civil rights movement was a youth movement. Although historians frequently date the origins of the struggle for racial equality to either the 1954 US Supreme Court decision or to the bus boycott in Montgomery, Alabama, the following year which launched the career of Dr. Martin Luther King, Jr., the true beginning of the mass movement occurred in February 1960 when four young black men sat in at a lunch counter in Greensboro, North Carolina, launching the sit-ins and direct action protests throughout the South. The sit-ins were crucial in recruiting black and white youths in the South to the cause of racial justice. In that sense, the direct action movement reflected the growing youth culture of the 1950s and 1960s and became an essential part of the civil rights struggle.

Second, the civil rights movement marked the coming-of-age of American television. This medium already had significant influence during the early part of the Confident Years as shows such as "Father Knows Best," "Ozzie and Harriet," and "The Mickey Mouse Club" depicted the wholesomeness of American family life. The ideal would suddenly become the real in the 1960s, however, as the civil rights movement became the first major social event televised nationally, and then the Kennedy assassination provided Americans with a front-row seat to tragedy. The key moment for the civil rights movement occurred in March 1965 when ABC interrupted its immensely popular program, the "ABC Sunday Night Movie" to show viewers the scene in Selma, Alabama, where state highway patrolmen were pursuing unarmed voting rights demonstrators with tear gas and rubber hoses wrapped in barbed wire. The demonstrators had attempted to cross a bridge on the road to the state capital when the troopers attacked them. Millions of Americans saw the brutality of Southern white resistance to racial equality and they pressured their representatives in Congress to do something about it. The result was the landmark 1965 Voting Rights Act signed by President Lyndon B. Johnson in August 1965. Incidentally, the film that March night was "Judgment at Nuremberg," about the Nazi war crimes trials just after World War II. 
Third, the civil rights movement defined the Confident Years because of its direct appeal to basic American ideals. Though the concept of racial equality may have been revolutionary to white Southerners, the appeal of the civil rights demonstrators was essentially conservative. When Martin Luther King, Jr. stood on the steps of the Lincoln Memorial in August 1963 to deliver his famous "I Have a Dream" speech, he quoted not Marx or Lenin, but a slaveholder, Thomas Jefferson: "All men are created equal, and they are endowed by their Creator with certain inalienable rights, among them life, liberty, and the pursuit of happiness."

Finally, the civil rights movement reflected a growing trend during the Confident Years, the increasing power and influence of federal legislation. The movement to suburbia, the growth of higher education, the construction of interstate highways, and the redevelopment of cities all became federal priorities during the Confident Years. These measures fundamentally changed how Americans lived their lives. The same can be said of the two major pieces of legislation to come out of the civil rights movement: the 1964 Civil Rights Act which struck down racial segregation by law, and the 1965 Voting Rights Act which enabled African Americans, particularly in the South, to vote. These measures resulted in significant social and political changes, especially in the South.

The legacy of the civil rights movement, especially its legacy in the American South after 1965, diverged from the second era of the 1960s, a time when the US was "Shaken to the Roots," as I put it in The American Journey. This divergence reflects the regional nature of the civil rights movement and its impact after 1965. Just five days after President Johnson signed the Voting Rights Act, the predominantly-black section of Watts in Los Angeles burst into flames as a result of racial strife, thus triggering a four-year period of long-hot summers of simmering and sometimes exploding racial tension. The Vietnam War and then Watergate further shook the confidence of the American people. The legacy of the civil rights movement, a primarily-southern phenomenon, provided one of the few rays of confidence in an otherwise dreary period of American history. In the years after 1965, as northern cities struggled economically and experienced unprecedented racial strife, the South prospered. After a century of net migration out of the South, Americans started moving in. The regional shift in population, prosperity, and political power was underway.

Second, the stability that accompanied the solution to the South's civil rights problems ushered in a two-party era, as the Republicans competed against the one-time political monopoly held by the Democrats. The results were more progressive Democratic politicians and growing political power for the South in the Congress and, eventually, with the election of Jimmy Carter in 1976, in the White House.

Finally, the South came to be known as the "Sunbelt," a benign, happy place where peace and prosperity had triumphed (in contrast with the rest of the country), and where everyone seemed to get along. Businesses, tired of confronting issues of crime, high taxes, and labor unions, moved south. Growing southern power in the Congress drew federal funds into southern states and cities furthering economic development. Though the South was not quite the Eden depicted in this perspective, the contrast between peaceful southern cities and the contentious urban North struck journalists and other publicists in particular.

These developments underscored the distinctive regional context of the civil rights movement, an event that scarcely touched the North, but that launched an era of economic and political power in the American South. The ultimate objectives of the civil rights movement - racial equality, especially economic and social equality - remain unfulfilled, though significant progress has occurred since the 1960s when the two words that defined life in the South "White" and "Colored" disappeared from the landscape, and the political disfranchisement of blacks ended. Despite the difficulties involved in joining the two races, the demise of racial segregation - an event that seemed impossible forty years ago - like the fall of the Berlin Wall and the landing of a man on the moon, came to pass. So will the ultimate objectives of the civil rights movement. Within our lifetime we can join the great nineteenth century African American leader Frederick Douglass who, responding to his 
own question of whether black and white Americans could learn to live together in harmony and equality, stated, "I believe we can."

(C) David Goldfield 